\title{
Microstructure and Corrosion Behavior of Brazed Joints of SiC/SiC Composites and Hastelloy N Alloy Using Cu-Ni Alloy
}

\author{
WANG Hongda ${ }^{1,2}$, FENG Qian ${ }^{3}$, YOU Xiao ${ }^{1,2,4}$, ZHOU Haijun ${ }^{1,2}$, \\ HU Jianbao ${ }^{1,2}$, KAN Yanmei ${ }^{1,2}$, CHEN Xiaowu ${ }^{1,2}$, DONG Shaoming ${ }^{1,2}$
}

(1. State Key Laboratory of High Performance Ceramics and Superfine Microstructure, Shanghai Institute of Ceramics, Chinese Academy of Sciences, Shanghai 200050, China; 2. Structural Ceramics and Composites Engineering Research Center, Shanghai Institute of Ceramics, Chinese Academy of Sciences, Shanghai 200050, China; 3. Analysis and Testing Center, Donghua University, Shanghai 201600, China; 4. University of Chinese Academy of Sciences, Beijing 100039, China)

\begin{abstract}
SiC}$ fibers reinforced $\mathrm{SiC}$ ceramic matrix composites were brazed to Hastelloy $\mathrm{N}$ alloy using $\mathrm{Cu}-2.67 \mathrm{Ni}$ (mass percentage) alloy. The obtained joints were corroded in FLiNaK molten salt at $800{ }^{\circ} \mathrm{C}$ for $100 \mathrm{~h}$. Microstructure evolution and corrosion behavior of joints were characterized. Alloy elements, e.g. $\mathrm{Ni}, \mathrm{Cr}$ and $\mathrm{Mo}$, diffuse from Hastelloy $\mathrm{N}$ alloy into $\mathrm{Cu}-\mathrm{Ni}$ joint seam, while the $\mathrm{Si}$ element in $\mathrm{SiC} / \mathrm{SiC}$ composites diffuses into joint seam even the Hastelloy $\mathrm{N}$ alloy. $\mathrm{Cr}$ element enriches near the interface between $\mathrm{SiC}$ composites and joint alloy to form discontinuity interlayer, which acts as the active metal instead of Ni. Higher temperature contributes to both the diffusion process and the erosion of $\mathrm{SiC}$ by $\mathrm{Ni}$, and lower temperature would lead to the incomplete fusion of brazing fillers. The diffusion of elements during the brazing changes the composition of the joint seam and Hastelloy $\mathrm{N}$ alloy, which caused the deterioration of corrosion resistance of alloy. The selective corrosion of $\mathrm{Cr}$ and $\mathrm{Si}$, supported by thermodynamic calculation, results in the corrosion of both joint seam and alloy.
\end{abstract}

Key words: $\mathrm{SiC} / \mathrm{SiC}$ composites; Hastelloy $\mathrm{N}$ alloy; $\mathrm{Cu}-\mathrm{Ni}$ alloy; brazing joint; corrosion behavior

Ceramic matrix composite is a kind of excellent material for extreme service environment application ${ }^{[1-2]}$. Among this kind of material, $\mathrm{SiC}$ fibers reinforced $\mathrm{SiC}$ ceramic matrix composites (i.e. $\mathrm{SiC} / \mathrm{SiC}$ composites) have been applied in critical structural applications because of their outstanding oxidation resistance property ${ }^{[3]}$ and superior high-temperature mechanical properties ${ }^{[4-5]}$. More recently, the $\mathrm{SiC} / \mathrm{SiC}$ composites have been considered as one of the ideal candidate structure materials for the Molten Salt Reactor (MSR) and the Advanced High Temperature Reactor (AHTR), owing to their good irradiation-resistance property $^{[6-7]}$, the compatibility to liquid fluoride salt ${ }^{[8-11]}$, and low activity ${ }^{[12]}$. Control rod, tie bar, fuel cladding and sleeve in the fuel assembly, the heat exchanger and the coolant loop in MSR and AHTR ${ }^{[13]}$ can be made of SiC/SiC composites. Most of such applications above in reactors require $\mathrm{SiC} / \mathrm{SiC}$ composites to join alloy materials, such as Hastelloy $\mathrm{N}$ alloy, a kind of Ni-based alloy with good corrosion resistance to fluoride salt, or $\mathrm{SiC} / \mathrm{SiC}$ compos- ites themselves.

The joint of $\mathrm{SiC} / \mathrm{SiC}$ composites for nuclear energy systems has some special requirements, e.g., hermeticity, high-temperature mechanical property and good compatibility to the working medium. The joining of $\mathrm{SiC} / \mathrm{SiC}$ composites for fusion reactor has been developed via using SiC-based preceramic polymer, for example, methyl-hydroxyl-siloxane and polyhydrido-methyl-siloxane (PHMS) ${ }^{[14]}$, which transforms into ceramics when being pyrolyzed at high temperature, yielding an adhesive bonding with SiC-based materials. Slurry composed of preceramic polymer and solid powders, like $\mathrm{SiC}$, has also been utilized to prepare ceramic joint of $\mathrm{SiC} / \mathrm{SiC}$ composites. However, the joint of $\mathrm{SiC} / \mathrm{SiC}$ composites to alloy for application in salt-cooled nuclear energy systems has rarely been reported.

Compared with mechanical joining, diffusion bonding, and reaction forming, brazing requires lower temperature with less influence on joined materials and could obtain

\footnotetext{
Received date: 2021-06-18; Revised date: 2021-07-14; Published online: 2021-08-20

Foundation item: National Natural Science Foundation of China (51802329)

Biography: WANG Hongda (1989-), male, associate professor. E-mail: wanghd@mail.sic.ac.cn 王洪达(1989-), 男, 副研究员. E-mail: wanghd@mail.sic.ac.cn

Corresponding author: ZHOU Haijun, associate professor. E-mail: zhouhj00000@mail.sic.ac.cn 周海军, 副研究员. E-mail: zhouhj00000@mail.sic.ac.cn
} 
dense joint with good hermeticity ${ }^{[15]}$. Active metal brazing is a simple and cost-effective technique to join ceramics to metal. Ni-based ${ }^{[16]}$, Ag-based ${ }^{[17-18]}$, Co-based ${ }^{[19]}$ and some other filler metals have been developed to brazing $\mathrm{SiC} / \mathrm{SiC}$ composites to alloys. Most of these researches focus on the wetting ability of brazing filler metal on $\mathrm{SiC}$ composites and the improvement of mechanical properties of joint at service temperature. Therefore, few study concentrates on the corrosion resistance performance of the joint of $\mathrm{SiC} / \mathrm{SiC}$ composites to alloys, especially in the high-temperature molten fluoride salt environment.

$\mathrm{Cu}-\mathrm{Ni}$ binary alloy has been applied as the inert anode in electrolysis cell with an electrolyte composed of cryolite, aluminum fluoride, magnesium fluoride, and so on ${ }^{[20]}$. This suggests the good corrosion resistance of $\mathrm{Cu}-\mathrm{Ni}$ alloy to fluoride salt. Moreover, although $\mathrm{Cu}$ is nonwetting on the $\mathrm{SiC}$, Ni could react with $\mathrm{SiC}$ at high temperature ${ }^{[21]}$, which means that $\mathrm{Ni}$ may play the role of active metal during the brazing process.

In this work, $\mathrm{Cu}-2.67 \mathrm{Ni}$ binary alloy was used to join $\mathrm{SiC} / \mathrm{SiC}$ composites to the Hastelloy $\mathrm{N}$ alloy. The influence of brazing temperature on the joint microstructure was studied, and the corrosion behavior of obtained joint was also analyzed.

\section{Experimental procedure}

\subsection{Materials}

The composites used in this work were two-dimensional woven fabrics of KD-II SiC fibers (National University of Defense Technology, China) reinforced $\mathrm{SiC}$ ceramic matrix composites. The $\mathrm{SiC} / \mathrm{SiC}$ composites were prepared via chemical vapor infiltration (CVI) processing, using the methyltrichlorosilane as raw material and $\mathrm{H}_{2}$ as the carrier gas. In advance of the CVI processing, a pyrolytic carbon (PyC) monolayer about $100 \mathrm{~nm}$ in thickness was deposited on the surface of SiC fibers through chemical vapor deposition (CVD). The $\mathrm{SiC} / \mathrm{SiC}$ composites were cut into $8 \mathrm{~mm} \times 5 \mathrm{~mm} \times 2 \mathrm{~mm}$ pieces. The Ni-based superalloy, Hastelloy $\mathrm{N}$ alloy, with a nominal mass composition of $68.77 \% \mathrm{Ni}, 18.90 \% \mathrm{Mo}, 7.01 \% \mathrm{Cr}, 4.18 \% \mathrm{Fe}$, $0.41 \% \mathrm{Si}, 0.47 \% \mathrm{Mn}$, and $0.26 \% \mathrm{Al}$, was provided by Institute of Metal Research, Chinese Academy of Sciences. The Hastelloy $\mathrm{N}$ alloy bulk was sectioned into $10 \mathrm{~mm} \times 10 \mathrm{~mm} \times 5 \mathrm{~mm}$ blocks. All materials were cleaned by acetone in an ultrasonic cleaner and then dried in a vacuum drying chamber for the brazing experiment.

The $\mathrm{Cu}$ powders $(99.7 \%, 80 \mu \mathrm{m}(200 \mathrm{mesh}))$ and $\mathrm{Ni}$ powders $(99.5 \%, 80 \mu \mathrm{m}(200$ mesh)) were obtained from Sinopharm Chemical Reagent Co., Ltd. According to the
Cu-Ni binary system diagram ${ }^{[22]}$, the continuous solid solution with FCC structure is in all ranges of composition. Considering the deterioration of $\mathrm{SiC} / \mathrm{SiC}$ composites over high temperature ${ }^{[23]}$, brazing temperature should be as low as possible, which meant that the content of $\mathrm{Ni}$ would be small. On the other hand, Ni was employed as the reactive metal to improve the wettability, indicating that enough Ni should be contained. Based on the requirements above, brazing alloy composed of $97.12 \mathrm{Cu}-$ $2.88 \mathrm{Ni}$ (in atom fraction), or $97.33 \mathrm{Cu}-2.67 \mathrm{Ni}$ (in weight fraction) was chosen to braze the $\mathrm{SiC} / \mathrm{SiC}$ composites to Hastelloy $\mathrm{N}$ alloy. In addition, a solution of polyvinyl butyral (PVB) in cyclohexanone, with a concentration of $3 \%-5 \%$ (mass percentage), was introduced as the binder to prepare the brazing paste.

\subsection{Brazing experiment}

The joining process of $\mathrm{SiC} / \mathrm{SiC}$ composites to Hastelloy $\mathrm{N}$ alloy was as follows: Firstly, $\mathrm{Cu}$ powders and $\mathrm{Ni}$ powders weighted in the desired composition were mixed mechanically with binder in an agate mortar to prepare a brazing paste. Secondly, the paste was brushed onto the surfaces of both $\mathrm{SiC} / \mathrm{SiC}$ composites (parallel to the fiber fabrics) and Hastelloy $\mathrm{N}$ alloy. Then the composites pieces were stacked on the alloy blocks face-to-face to form a sandwich-like structure (as shown in Fig. 1). After drying, the assembly was put into the vacuum furnace and heated to $1090,1110,1130$, and $1150{ }^{\circ} \mathrm{C}$ at a rate of $10{ }^{\circ} \mathrm{C} / \mathrm{min}$ for $10 \mathrm{~min}$, respectively. During the cooling of furnace, a cooling rate of $10{ }^{\circ} \mathrm{C} / \mathrm{min}$ was controlled above $500{ }^{\circ} \mathrm{C}$, then followed by natural cooling to room temperature.

\subsection{Corrosion experiment}

After brazing, the obtained brazing joint of $\mathrm{SiC} / \mathrm{SiC}$ composites to Hastelloy $\mathrm{N}$ alloy was dipped into the $50 \mathrm{~g}$ 46.5 LiF-11.5NaF-42.0KF (mole fraction, FLiNaK) eutectic fluoride salt (Shanghai Institute of Organic Chemistry, Chinese Academy of Sciences) contained in the graphite crucible. Following, the crucible was heated at $800{ }^{\circ} \mathrm{C}$ in the furnace for $100 \mathrm{~h}$. Here, it should be mentioned that all above operations were conducted in a glove box under the protection of high purity argon gas. The atmosphere in the glove box was controlled at $\mathrm{O}_{2}<10^{-5} \%$

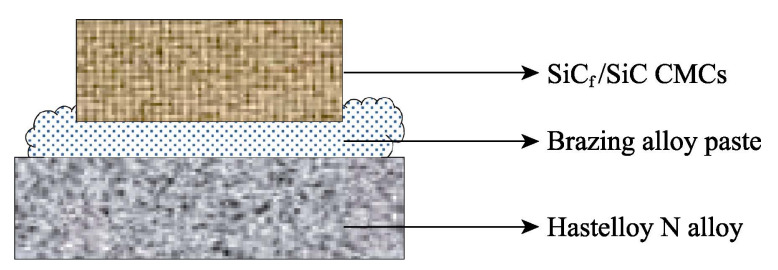

Fig. 1 Schematic illustration of the sandwich-like structure of joint 
(in volume) and moisture $<10^{-5} \%$ (in volume) in the corrosion process. After the high-temperature corrosion process in molten fluoride salt, the joint samples were picked out from the crucible and immersed into $1 \mathrm{~mol} / \mathrm{L}$ $\mathrm{Al}\left(\mathrm{NO}_{3}\right)_{3}$ solution to remove the fluoride salt solid adhering on the sample surfaces and penetrating into the inside $^{[24]}$. Finally, the samples were cleaned by ultrasonication in deionized water, then dried in a vacuum drying chamber.

\subsection{Characterization}

The obtained brazing joint samples before and after corrosion were cut along the direction perpendicular to the brazing plane to expose the cross-section. Then the cross-sections were polished and ultrasonically cleaned in acetone. The scanning electron microscope (SEM, Quanta-250, FEI, USA) coupled with energy dispersive spectrometer (EDS, Oxford, UK) was employed to characterize the microstructure and distribution of elements in joint samples. The inductively coupled plasma atomic emission spectrometry (ICP-AES, Vista AX, VARIAN, USA) was used to analyze the impurity composition in fluoride salt before and after the corrosion process.

\section{Results and discussion}

\subsection{Microstructure of brazing joints}

The joints of $\mathrm{SiC} / \mathrm{SiC}$ composites to Hastelloy $\mathrm{N}$ alloy were obtained at $1090-1130{ }^{\circ} \mathrm{C}$, while no joint was obtained at $1150{ }^{\circ} \mathrm{C}$ because of the damage of $\mathrm{SiC}$ composites. The microstructure of joints evolution of $\mathrm{SiC} / \mathrm{SiC}$ composites to Hastelloy $\mathrm{N}$ alloy at varying temperatures is shown in Fig. 2. When brazed at 1090 and $1110{ }^{\circ} \mathrm{C}$, voids (pointed by a red ellipse in Fig. 2(a) and black arrows in Fig. 2(b)) existed in the brazing alloy because of the incomplete fusion of brazing powders and poor fluidity of liquid metal. When brazed at $1130{ }^{\circ} \mathrm{C}$, the dense joint, which was well-bonded to both $\mathrm{SiC} / \mathrm{SiC}$ composites and Hastelloy $\mathrm{N}$ alloy and devoid of imperfections, such as cracks and voids, was obtained. The thickness of the brazed seam was $\sim 200 \mu \mathrm{m}$. The elemental mappings of the joint obtained at $1130{ }^{\circ} \mathrm{C}$ shown in Fig. 3 indicated that elements in the Hastelloy $\mathrm{N}$ alloy, e.g. $\mathrm{Ni}, \mathrm{Mo}$, and $\mathrm{Cr}$, diffused into the seam area. $\mathrm{Cu}$ and $\mathrm{Ni}$ diffused into the composites, while Si element moved into the weld area. Both $\mathrm{Ni}$ and $\mathrm{Cr}$ elements are enriched at the interface between $\mathrm{SiC} / \mathrm{SiC}$ composites and seam, indicating their reactions with $\mathrm{SiC}$. High magnification image (Fig. 2(d)) of a blue rectangular area in Fig. 2(c) showed the detail of reaction area between $\mathrm{SiC}$ and brazed seam. The gray reaction layer was observed. According to the EDS results (Fig. 2(e)), the gray layer (point 1 in

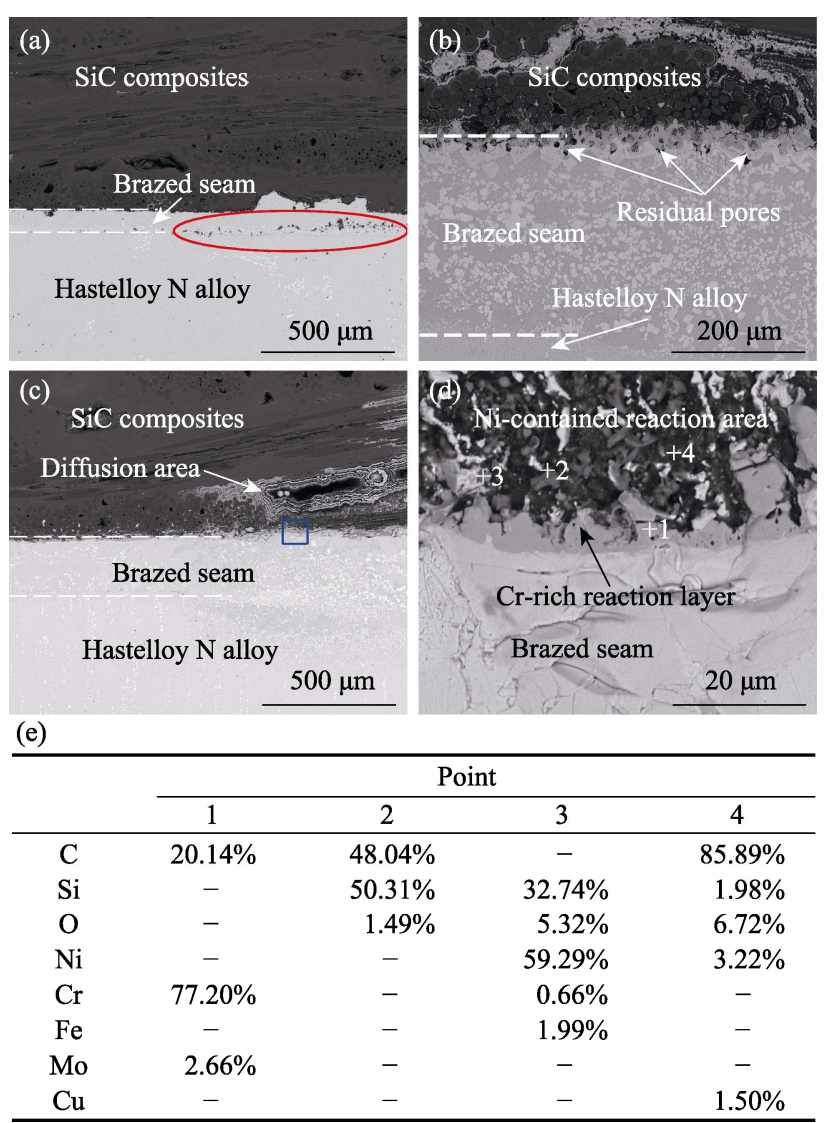

Fig. 2 SEM images of brazing joints obtained at (a) 1090, (b) $1110,(\mathrm{c}, \mathrm{d}) 1130{ }^{\circ} \mathrm{C}$, correspoding EDS analyses (atom fraction) (e) of the point in image (d)
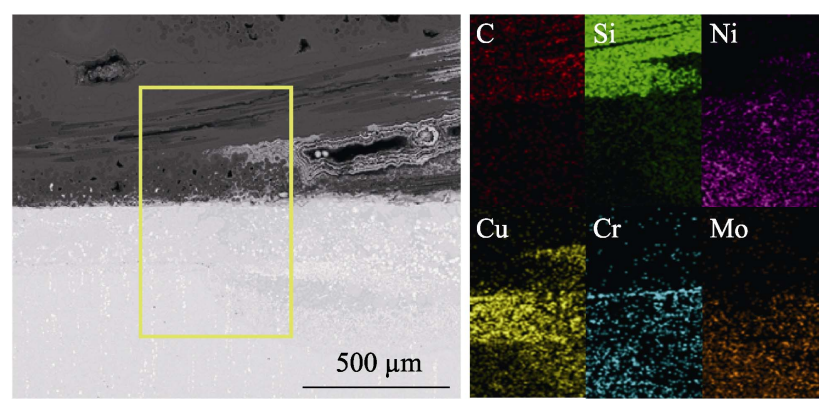

Fig. 3 Elemental distribution analyses by EDS of joint obtained at $1130{ }^{\circ} \mathrm{C}$

Fig. 2(d)) mainly consisted of $\mathrm{Cr}$ and $\mathrm{C}$ and would be the product of the reaction between $\mathrm{Cr}$ and $\mathrm{SiC}$. The C-rich area (point 4) and the Ni-Si area (point 3) were observed. Furthermore, when the temperature increases to $1150{ }^{\circ} \mathrm{C}$, over diffusion and reaction between diffused metal and $\mathrm{SiC}$ at $\mathrm{SiC} / \mathrm{SiC}$ composites side happened, which led to the failure of forming joint.

Compared with $\mathrm{Ni}$, the designed active element in brazing filler, $\mathrm{Cr}$ plays the role of the active element in brazing alloy more frequently, for instance, the PdNi-Cr-V alloy $^{[25]}$. According to Park, et $a l^{[21]}, \mathrm{Cr}$ is one of the type II elements, while Ni belongs to the type I metal. 
The products of the reaction between $\mathrm{Cr}$ and $\mathrm{SiC}$ are chromium carbides and chromium silicides, while $\mathrm{Ni}$ reacts with $\mathrm{SiC}$ to form nickel silicides and graphite. The thermodynamic calculation results shown in Fig. 4 reveal that the formation of reaction products is in order of $\mathrm{Cr}_{23} \mathrm{C}_{6}, \mathrm{Cr}_{7} \mathrm{C}_{3}, \mathrm{Ni}_{2} \mathrm{Si}, \mathrm{Cr}_{3} \mathrm{C}_{2}$, and $\mathrm{Cr}_{3} \mathrm{Si}$, which suggests that $\mathrm{Cr}$ has higher activity than $\mathrm{Ni}$ from $950{ }^{\circ} \mathrm{C}$ to $1150{ }^{\circ} \mathrm{C}$ and could react with $\mathrm{SiC}$ much easilier. This may be the reason that $\mathrm{Cr}$ acted as the active element and enriched at the interlayer area in the brazing process.

Microstructure of the over diffusion area in SiC composites obtained at $1150{ }^{\circ} \mathrm{C}$ and the EDS line-scan analyses are shown in Fig. 5. Three sections were observed in the reaction zone in composites in Fig. 5(a), the porous structure (Section I), the light gray area with cracks (Section II) and the dark gray (Section III). Line-scan analysis results in Fig. 5(c-e) showed that the light gray

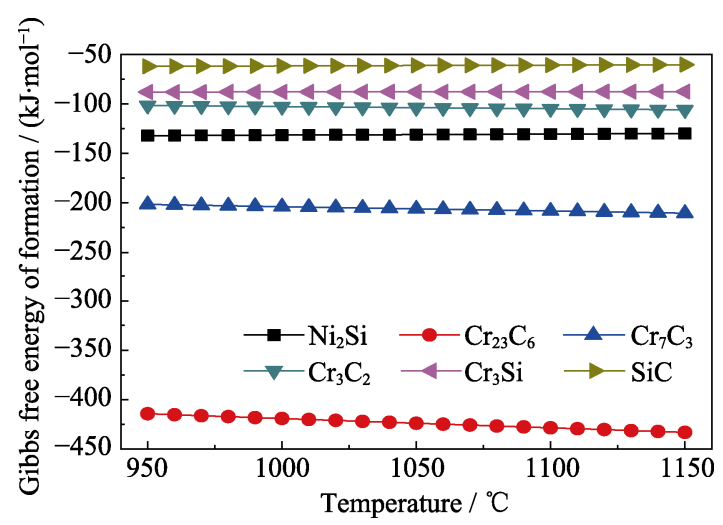

Fig. 4 Gibbs free energy of formation of candidates calculated using HSC Chemistry 5.11 computer software and its associated databases diffusion area was mainly composed of $\mathrm{Ni}$ and $\mathrm{C}$ with a little $\mathrm{Si}$, while the dark gray area was the SiC fibers and CVI SiC matrix, which implied that the Ni diffused from the filler and Hastelloy $\mathrm{N}$ alloy reacted with $\mathrm{SiC}$ fibers and CVI matrix seriously during the brazing at $1150{ }^{\circ} \mathrm{C}$. From section I to section III, the closer the section was to the brazing filler, the more serious the reaction damage would be.

XRD pattern of the brazed seam before and after corrosion is shown in Fig. 6. Particularly, the brazed seam pattern is obtained near the interface between the $\mathrm{SiC} /$ $\mathrm{SiC}$ composites and the seam. The major phase of the joint seam is $\mathrm{Cu}_{0.81} \mathrm{Ni}_{0.19}$, which is formed by alloying of $\mathrm{Cu}$ and Ni. Meanwhile, the peaks of $\mathrm{Cr}_{23} \mathrm{C}_{6}, \mathrm{Ni}$ and $\mathrm{Ni}_{2} \mathrm{Si}$ can be detected. It is concluded that $\mathrm{Cr}_{23} \mathrm{C}_{6}$ is the product of the diffused $\mathrm{Cr}$ and $\mathrm{SiC}$ or $\mathrm{C}$, which coincides with the EDS mapping and the thermodynamic calculation results. The appearance of $\mathrm{Ni}_{2} \mathrm{Si}$ is blamed for the reaction between $\mathrm{Ni}$ and $\mathrm{SiC}$, which can be seen in Fig. 5 . Moreover, $\mathrm{Cr}$ from Hastelloy $\mathrm{N}$ alloy and $\mathrm{Ni}$ is bound to react with $\mathrm{SiC}$ in the brazing progress. Considering the distribution of $\mathrm{Cr}$ and $\mathrm{Ni}, \mathrm{Cr}$ plays the role of active metal other than the $\mathrm{Ni}$ element. The detection of $\mathrm{Ni}$ might be the residual $\mathrm{Ni}$ introduced by brazing metal powders.

\subsection{Corrosion behavior}

The microstructure of joint obtained at $1130{ }^{\circ} \mathrm{C}$ before and after corrosion at $800{ }^{\circ} \mathrm{C}$ for $100 \mathrm{~h}$ are shown in Fig. 7. The elemental mapping results of the corroded joint are shown in Fig. 8. Compared with the microstructure of joint before corrosion, the microstructure of corroded joint contained holes in both brazing seam and Hastelloy
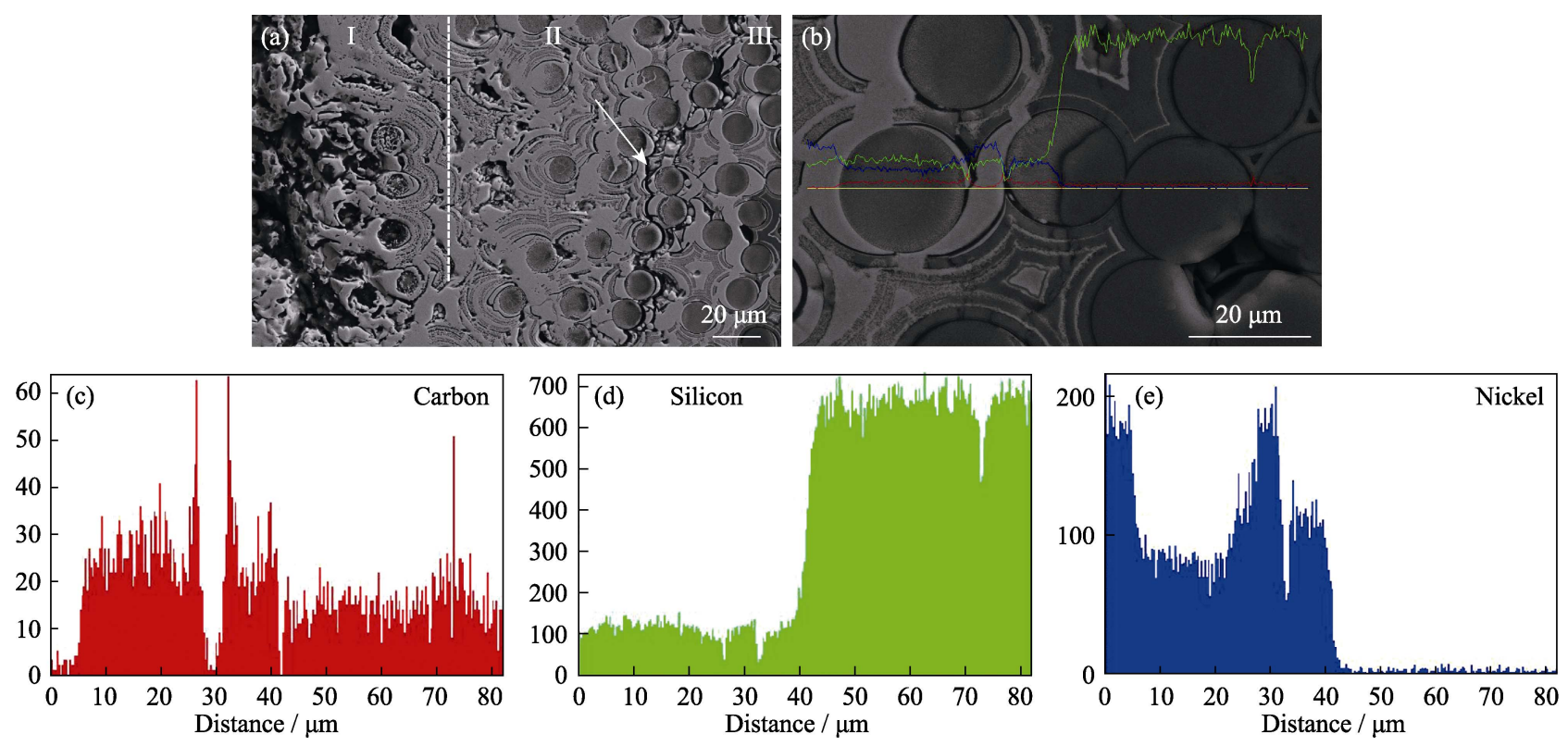

Fig. 5 SEM images of microstructure and EDS line-scan analyses in $\mathrm{SiC} / \mathrm{SiC}$ composites near joint obtained at $1150{ }^{\circ} \mathrm{C}$ 
$\mathrm{N}$ alloy, and the interlayer between $\mathrm{SiC} / \mathrm{SiC}$ composites and the joint seam was replaced by crack. $\mathrm{Cr}$ loss was observed in the corresponding area in EDS mapping results, meanwhile, the ICP-AES results shown in Table 1 gave the evidence of the $\mathrm{Cr}$ loss from the joint because of higher $\mathrm{Cr}$ content after corrosion than that before corrosion. In addition, there was a little $\mathrm{Si}$ in seam shown in the EDS mapping result in Fig. 8. These indicated that the corrosion of joint seam and alloy might be caused by

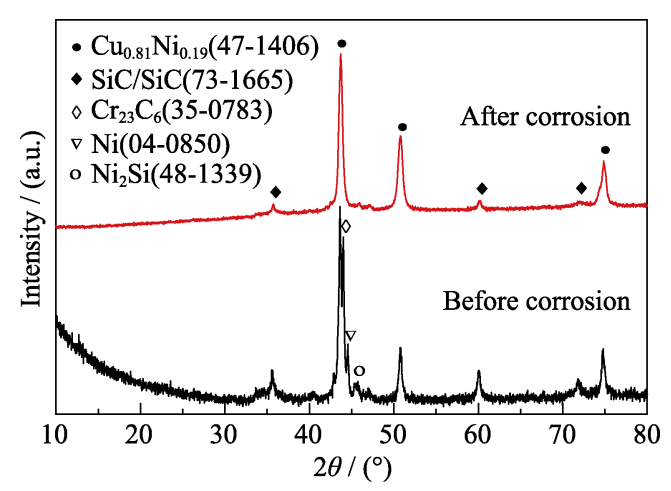

Fig. 6 XRD patterns of joints before and after corrosion
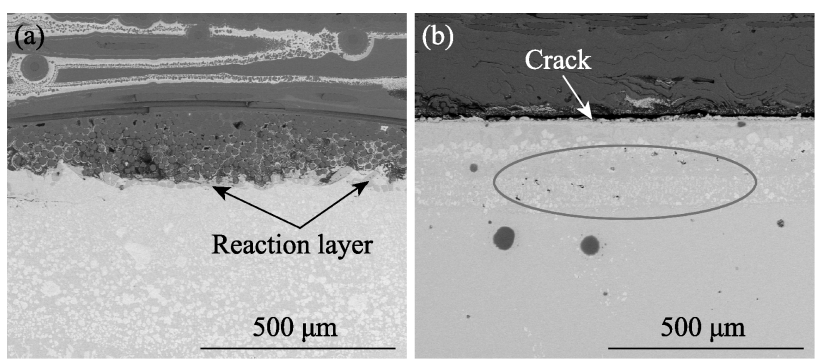

Fig. 7 Appearance images and SEM images of microstructures of joints before and after corrosion at $800{ }^{\circ} \mathrm{C}$ for $100 \mathrm{~h}$

Table 1 Content of main metal impurities in fluoride salts before and after corrosion $\left(10^{-4} \%\right.$ in mass $)$

\begin{tabular}{ccc}
\hline Element & Before corrosion & After corrosion \\
\hline $\mathrm{Ni}$ & 10 & 20 \\
$\mathrm{Cr}$ & 20 & 210 \\
$\mathrm{Fe}$ & 30 & 40 \\
$\mathrm{Mo}$ & $<10$ & $<10$ \\
\hline
\end{tabular}

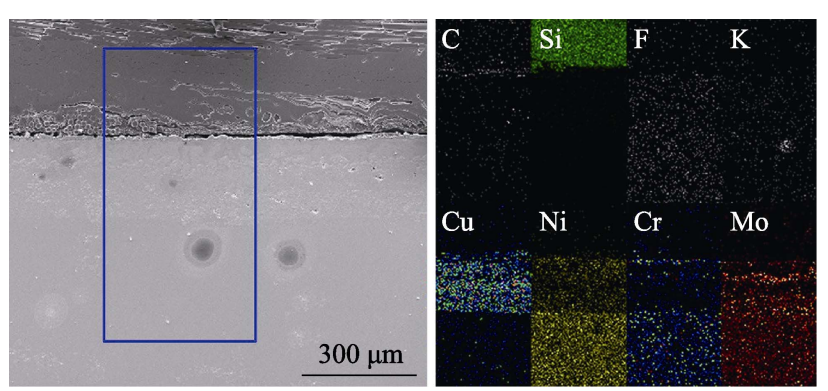

Fig. 8 Elemental distribution analyses by EDS of joint obtained at $1130{ }^{\circ} \mathrm{C}$ after corrosion at $800{ }^{\circ} \mathrm{C}$ for $100 \mathrm{~h}$ the optional corrosion of diffused $\mathrm{Cr}$ and $\mathrm{Si}$. Liquid salt infiltrated into the seam through the holes to erode the Cr-contained interlayer, which was confirmed by the disappearance of $\mathrm{Cr}$-rich interlayer in the elemental mapping results and leaded to the appearance of cracks in Fig. 8.

On the other aspect, the red XRD pattern of the corroded joint presented in Fig. 6 shows that the phase composition changed during the corrosion. The peak of $\mathrm{Cr}_{23} \mathrm{C}_{6}$ disappeared, while the $\mathrm{Cu}_{0.81} \mathrm{Ni}_{0.1}$, $\mathrm{SiC} / \mathrm{SiC}$ composites, and $\mathrm{Ni}_{2} \mathrm{Si}$ still remained. It is concluded that fluoride salt corrodes the Cr-contained phase selectively. That is to say, the well-bonded reaction interlayer should have good compatibility with fluoride salt at high temperature.

$\mathrm{Cr}$ in Hastelloy $\mathrm{N}$ alloy has worse corrosion resistance to molten fluoride salt, and would be corroded and dissolved selectively ${ }^{[26]}$, while $\mathrm{Si}$ has the compatibility problem with liquid fluoride salt, which has been discussed by Schmidt, et al. ${ }^{[27]}$ This explains the corrosion of joint seam and alloy. However, the selective corrosion of $\mathrm{Cr}$ in Hastelloy $\mathrm{N}$ alloy is much slower than that shown in this experiment. The change of composition and microstructure of alloy should be blamed for the worse corrosion. As discussed above, $\mathrm{Cr}$ from the alloy plays the role of active metal in the brazing process. The diffusion of $\mathrm{Ni}, \mathrm{Cr}$ from alloy to brazing alloy, and the diffusion of $\mathrm{Cu}$ into alloy changed the composition and microstructure of Hastelloy $\mathrm{N}$ alloy, resulting in more serious degradation of corrosion resistance performance.

According to Sellers, et al. ${ }^{[28]}, \mathrm{H}_{2} \mathrm{O}$ impurity contained in FLiNaK would produce $\mathrm{HF}$ :

$$
\begin{aligned}
\mathrm{H}_{2} \mathrm{O}+2 \mathrm{~F}^{-} & =\mathrm{O}^{2-}+2 \mathrm{HF} \\
\mathrm{H}_{2} \mathrm{O}+\mathrm{F}^{-} & =\mathrm{OH}^{-}+\mathrm{HF}
\end{aligned}
$$

$\mathrm{HF}$ would react preferentially with $\mathrm{Cr}$ :

$$
\mathrm{Cr}+2 \mathrm{HF}=\mathrm{CrF}_{2}+\mathrm{H}_{2}
$$

Because of the graphite crucible, the $\mathrm{CrF}_{2}\left(\mathrm{Cr}^{2+}\right)$ dissolved in the fluoride salt diffuses to graphite surface to form $\mathrm{Cr}_{7} \mathrm{C}_{3}$, which was reported by Ozeryanaya ${ }^{[29]}$.

$$
21 \mathrm{CrF}_{2}+3 \mathrm{C}=14 \mathrm{CrF}_{3}+\mathrm{Cr}_{7} \mathrm{C}_{3}
$$

The formed $\mathrm{CrF}_{3}$ dissolved into the molten salt and diffused back to the corroded sample. In the joint corrosion processing, the $\mathrm{CrF}_{3}$ could contribute to both the alloy corrosion and the joint seam corrosion. The corrosion reaction of $\mathrm{Cr}$ in Hastelloy $\mathrm{N}$ alloy and joint seam caused by $\mathrm{CrF}_{3}\left(\mathrm{Cr}^{3+}\right)$ would be as follows ${ }^{[29]}$ :

$$
2 \mathrm{CrF}_{3}+\mathrm{Cr}=3 \mathrm{CrF}_{2}
$$

The formed $\mathrm{CrF}_{2}$ through reaction (5) dissolved into the liquid salt, diffused to the joint and accelerated the selective corrosion of $\mathrm{Cr}$ by reaction (4). That is to say, the brazing filler should not change the composition of the alloy or serve as the diffusion media for the alloy 
elements in order to keep the corrosion resistance of Hastelloy $\mathrm{N}$ alloy. On the other hand, the corrosion behavior of Cr-rich interlayer is still unknown, which should be further studied.

Because of the unique extremely environment, the brazing joint between $\mathrm{SiC} / \mathrm{SiC}$ composites and Hastelloy $\mathrm{N}$ alloy for liquid fluoride salt environment needs to consider more specific facts. Based on the above experimental results, some roles can be drawn. On the one hand, the active composition and its reaction products should present good compatibility with liquid fluoride salt. On the other hand, to maintain the corrosion resistance property, the brazing materials should not change the composition and microstructure of Hastelloy $\mathrm{N}$ alloy. Therefore, for solving these two problems simultaneously, more efforts are needed to be paid on designing and seeking new suitable brazing filler materials system and finding bonded mechanism that meets these requirements.

\section{Conclusion}

$\mathrm{Cu}-2.67 \mathrm{Ni}$ (weight fraction) alloy was used to brazing $\mathrm{SiC} / \mathrm{SiC}$ composites to Hastelloy $\mathrm{N}$ alloy. The sound joint was obtained at $1130{ }^{\circ} \mathrm{C}$ for $10 \mathrm{~min}$. Lower brazing temperature leads to the appearance of holes because of the incomplete fusion metal powders and poor fluidity, while higher brazing temperature contributes to the over diffusion of $\mathrm{Ni}$ and the over reaction between $\mathrm{Ni}$ and $\mathrm{SiC}$ to form the brittle Ni-Si compounds, leading to the appearance of cracks and vesicular damaged area. $\mathrm{Cr}$ element from Hastelloy $\mathrm{N}$ alloy diffused into the joint seam and acted with $\mathrm{SiC}$ as active element together with $\mathrm{Ni}$. In the corrosion process, $\mathrm{Cr}$ in joint seam and Hastelloy $\mathrm{N}$ alloy and $\mathrm{Si}$ in seam were selectively corroded. Serious $\mathrm{Cr}$ loss confirmed by the ICP-AES result suggests the unsatisfied corrosion resistance of $\mathrm{Cu}-2.67 \mathrm{Ni}$ joint of $\mathrm{SiC} / \mathrm{SiC}$ composites and Hastelloy $\mathrm{N}$ alloy to FLiNaK molten salt.

\section{References:}

[1] KRENKEL W. Ceramic Matrix Composites: Fiber Reinforced Ceramics and their Applications. Weinheim: John Wiley \& Sons, 2008.

[2] PI H, SONG F, WANG H, et al. Influence of copper contamination on ablation damage of $\mathrm{C} / \mathrm{SiC}$ composites under simulated thermal environment of arc heater. Ceramics International, 2021, 47(15): 22016-22024.

[3] LEE K N, MILLER R A. Oxidation behavior of muilite-coated SiC and $\mathrm{SiC} / \mathrm{SiC}$ composites under thermal cycling between room temperature and $1200{ }^{\circ} \mathrm{C}-1400{ }^{\circ} \mathrm{C}$. Journal of the American Ceramic Society, 1996, 79(3): 620-626.

[4] GOMINA M, FOURVEL P, ROUILLON M H. High temperature mechanical behaviour of an uncoated $\mathrm{SiC}-\mathrm{SiC}$ composite material. Journal of Materials Science, 1991, 26(7): 1891-1898.

[5] JACOBSEN T K, BR NDSTED P. Mechanical properties of two plain-woven chemical vapor infiltrated silicon carbide-matrix composites. Journal of the American Ceramic Society, 2001, 84(5): 1043-1051.

[6] KATOH Y, OZAWA K, HINOKI T, et al. Mechanical properties of advanced $\mathrm{SiC}$ fiber composites irradiated at very high temperatures. Journal of Nuclear Materials, 2011, 417(1): 416-420.

[7] JONES R H, HENAGER C H. Fusion reactor application issues for low activation $\mathrm{SiC} / \mathrm{SiC}$ composites. Journal of Nuclear Materials, 1995, 219(2): 55-62.

[8] HE X, SONG J, TAN J, et al. SiC coating: an alternative for the protection of nuclear graphite from liquid fluoride salt. Journal of Nuclear Materials, 2014, 448(1): 1-3.

[9] NISHIMURA H, TERAI T, YONEOKA T, et al. Compatibility of structural candidate materials with $\mathrm{LiF}-\mathrm{BeF}_{2}$ molten salt mixture. Journal of Nuclear Materials, 2000, 283-287(Part 2): 1326-1331.

[10] YANG X, LIU M, GAO Y, et al. Effect of oxygen on the corrosion of $\mathrm{SiC}$ in LiF-NaF-KF molten salt. Corrosion Science, 2016, 103: $165-172$.

[11] WANG H, ZHOU H, DONG S, et al. Corrosion behavior of $\mathrm{SiC}_{\mathrm{f}} / \mathrm{SiC}$ composites in high temperature fluoride salt environment. Journal of Inorganic Materials, 2017, 32(11): 1133-1140.

[12] RICCARDI B, GIANCARLI L, HASEGAWA A, et al. Issues and advances in $\mathrm{SiC}_{\mathrm{f}} / \mathrm{SiC}$ composites development for fusion reactors. Journal of Nuclear Materials, 2004, 329-333(Part A): 56-65.

[13] WILLIAMS D F, TOTH L M, CLARNO K T. ORNL/TM-2006/12. Oak Ridge: Oak Ridge National Lab., 2006.

[14] HENAGER C H, SHIN Y, BLUM Y, et al. Coatings and joining for $\mathrm{SiC}$ and $\mathrm{SiC}$-composites for nuclear energy systems. Journal of Nuclear Materials, 2007, 367-370: 1139-1143.

[15] ZHANG Y, FENG D, HE Z Y, et al. Progress in joining ceramics to metals. Journal of Iron and Steel Research, 2006, 13(2): 1-5.

[16] SINGH M, ASTHANA R, SHPARGEL T P. Brazing of ceramicmatrix composites to Ti and Hastealloy using Ni-base metallic glass interlayers. Materials Science and Engineering: A, 2008, 498(1): 19-30.

[17] HATtali M L, VAletTe S, ROPITAL F, et al. Study of SiCnickel alloy bonding for high temperature applications. Journal of the European Ceramic Society, 2009, 29(4): 813-819.

[18] LIN G, HUANG J, ZHANG H. Joints of carbon fiber-reinforced $\mathrm{SiC}$ composites to Ti-alloy brazed by $\mathrm{Ag}-\mathrm{Cu}$-Ti short carbon fibers. Journal of Materials Processing Technology, 2007, 189(1): 256-261.

[19] XIONG H, LI X, MAO W, et al. Wetting behavior of Co based active brazing alloys on $\mathrm{SiC}$ and the interfacial reactions. Materials Letters, 2003, 57(22): 3417-3421.

[20] LU J, XIA Z. The corrosion performance of a binary Cu-Ni Alloy used as an anode for aluminum electrolysis. Applied Mechanics \& Materials, 2011, 55: 7-10.

[21] PARK J S, LANDRY K, PEREPEZKO J H. Kinetic control of silicon carbide/metal reactions. Materials Science and Engineering: A, 1999, 259(2): 279-286.

[22] FRANKE P, NEUSCH TZ D. Cu-Ni(Copper- Nickel)//FRANKE P, NEUSCH TZ D. Binary systems Part 3: Binary Systems from Cs-K to $\mathrm{Mg}-\mathrm{Zr}$ Heidelberg; Springer. 2005.

[23] ARAKI H, SUZUKI H, YANG W, et al. Effect of high temperature heat treatment in vacuum on microstructure and bending properties of $\mathrm{SiC}_{\mathrm{f}} / \mathrm{SiC}$ composites prepared by CVI. Journal of Nuclear Materials, 1998, 258-263(Part 2): 1540-1545.

[24] OLSON L C, AMBROSEK J W, SRIDHARAN K, et al. Evaluation of Material Corrosion in Molten Fluoride Salt. Proceedings of the Presentation on AIChE Conference, San-Francisco, F, 2006.

[25] XIONG H P, CHEN B, KANG Y S, et al. Wettability of Co-V, and 
PdNi-Cr-V system alloys on SiC ceramic and interfacial reactions. Scripta Materialia, 2007, 56(2): 173-176.

[26] OLSON L C, AMBROSEK J W, SRIDHARAN K, et al. Materials corrosion in molten LiF-NaF-KF salt. Journal of Fluorine Chemistry, 2009, 130(1): 67-73.

[27] SCHMIDT J, SCHEIFFELE M, CRIPPA M, et al. Design, fabrication, and testing of ceramic plat-type heat exchangers with integrated flow channel design. International Journal of Applied Ceramic
Technology, 2011, 8(5): 1073-1086.

[28] SELLERS R S, CHENG W J, ANDERSON M H, et al. Materials Corrosion in Molten LiF-NaF-KF Eutectic Salt under Different Reduction-oxidation Conditions. Proceedings of the International Conference Advances in Nuclear Power Plants (ICAPP'12), F, 2012.

[29] OZERYANAYA I N. Corrosion of metals by molten salts in heattreatment processes. Metal Science and Heat Treatment, 1985, 27(3): 184-188.

\title{
$\mathrm{SiC} / \mathrm{SiC}$-哈氏合金异质连接机制及其氟熔盐腐蚀特性分析
}

\author{
王洪达 ${ }^{1,2}$, 冯 倩 $^{3}$, 游 潇 ${ }^{1,2,4}$, 周海军 ${ }^{1,2}$, \\ 胡建宝 $^{1,2}$, 阚艳梅 ${ }^{1,2}$, 陈小武 ${ }^{1,2}$, 董绍明 1,2
}

(1. 中国科学院 上海硅酸盐研究所, 高性能陶瓷和超微结构国家重点实验室, 上海 200050; 2. 中国科学院 上海 硅酸盐研究所, 结构陶瓷与复合材料工程研究中心, 上海 200050；3. 东华大学 分析测试中心, 上海 $201600 ; 4$. 中国科学院大学, 北京 100039)

摘 要: 以 $\mathrm{Cu}-2.67 \mathrm{Ni}$ 钎料, 采用钎焊工艺获得了 $\mathrm{SiC} / \mathrm{SiC}$ 复合材料-哈氏合金异质接头, 并研究了其在 $800{ }^{\circ} \mathrm{C}$ 的 $\mathrm{FLiNaK}$ 熔盐中的腐蚀行为。利用不同手段表征了接头微观结构和氟熔盐腐蚀行为。结果表明, Ni、Cr、Mo 等合金 元素以及 $\mathrm{SiC}$ 中的 $\mathrm{Si}$ 元素发生互扩散。 $\mathrm{Cr}$ 元素替代 $\mathrm{Ni}$ 元素, 在焊料-复合材料界面富集并形成不连续碳化物层。 高温钎焊加速 $\mathrm{Ni}$ 扩散并侵蚀 $\mathrm{SiC}$, 低温钎焊导致焊料熔融不充分。钎焊过程中的元素扩散改变了哈氏合金的组成, 导致其耐腐蚀性能恶化。 $\mathrm{Cr}$ 与 $\mathrm{Si}$ 的选择性溶出导致钎焊接头及合金的腐蚀损伤，这与热力学计算结果一致。

关 键 词: $\mathrm{SiC} / \mathrm{SiC}$ 复合材料; 哈氏 $\mathrm{N}$ 合金; $\mathrm{Cu}-\mathrm{Ni}$ 合金; 钎焊接头; 腐蚀行为

中图分类号: TQ174 文献标志码: A 